\title{
Business Performance of Private Life Insurance Players in India
}

\author{
Dr.Harish M. Chandarana \\ Associate Professor \& Head, Department of Commerce, H.N.Doshi Arts and R.N.Doshi Commerce College, \\ Affiliated to Saurashtra University, India
}

\begin{abstract}
The insurance industry in India has witnessed many radial transformations during the last about Two Hundred years of its inception. Both the life insurance as well as the general insurance companies was nationalized by the government in the years 1956 and 1972 respectively. Financial reforms started in 1991 after adopting LPG policy by Indian government. In 1999, IRDA has been set up to regulate insurance sector. In 2000, Indian insurance market has been opened up for insurance players from all over the world with localized partnership.
\end{abstract}

$26 \%$ FDI in insurance sector was allowed in 2000 and increased to $49 \%$ in 2015. 1 public life insurance (LIC) and 23 private companies are registered life insurers in India. The private players have 6156 offices in India and captured some $27 \%$ market share of total premium already by the year 201415.

The entry of those foreign players in the Indian insurance industry has denatured the nature of competition and also enlarged customer consciousness. In this research paper, an attempt is made to measures the business performance of private life insurance players in India.

Keywords - Insurance Industry, LIC, IRDA, FDI, Market Share, Business Performance.

\section{INTRODUCTION}

The Indian Shelter Industry is as old as it is in any else of the world. In 1818 the firstborn of the shelter companies was started in Kolkatta, India. Ever since the insurance industry was nationalized in 1956 and In $1^{\text {st }}$ September 1956 the Life Insurance Corporation (LIC), a public insurance company, the monopoly grew in size and stature with every passing decennium. There was an important growth and employment in this sector after Indian Economic Modify 1991 which is defined by strategic elements LPG i.e. Liberalization, privatization and globalization.

The Insurance Regulatory and Development Authority (IRDA) were constituted as an autonomous body to regulate and develop the business of insurance and re-insurance in the country in terms of the Insurance Regulatory \& Development Authority Act, 1999. In August, 2000 IRDA invites application from foreign players with local partnership. 23 private and 1 public life insurance (LIC) companies are registered life insurers in India as on $30^{\text {th }}$ September, 2014.

The measure of shelter penetration and compactness reflects the stage of processing and development of this sector. Insurance perception is measured as the \% of total premium to GDP. Shelter density is measured as the ratio of premium to population (per capita premium)

In India, during the early decennary of insurance sector alleviation, according the sector has reported concordant growth in life insurance onset from $2.15 \%$ in 2001 to $4.40 \%$ in 2010. Yet, since then, the destroy of perception has been declining \& reached $3.10 \%$ in 2013 . This indicates that during the past 3 years the growth in shelter reward is berth than the development in subject GDP. A similar inclination was observed in the story of insurance spacing which reached the maximum of USD 55.7 in the year 2010 from the direct of USD 9.1 in 2001. During the year under review 2012-13, the insurance denseness was USD 41.0.

\section{NEED FOR THE STUDY}

Liberalization means a free economy where one can work without direct control of the government. The insurance market which was totally monopolized by public life insurance company LIC (Life Insurance Corporation of India) before LPG, now competition by Private Life Insurance players affects the business of LIC. Under the process of LPG, In India the insurance industry is now open and the new foreign players with localized partnership have already started capturing the life insurance marketplace acquire. The internationally reputed foreign life insurance companies have given wide range of products, good service and aware the people for life insurance results the rapid growth in business. One estimate is that the in life insurance sector, private players have captured some $27 \%$ market share of total premium already by the year 2014-15. FDI in insurance sector was allowed $26 \%$ in 2000 and was increased to $49 \%$ in 2015 . Only 4 private life insurance companies were registered in 2000 which is increased to 23 in 2015. So, in more than one decade private players have increased their market rapidly with 6156 offices in India. This is the reason; researcher is interested in finding the business performance of private life insurance companies in India.

\section{LITERATURE REVIEW}

1. Amisha H.Desai (2015) in her Ph.D research title "A comparative study of performance of selected private life insurance companies with LIC". She found that in spite of having 23 private companies working India, LIC is still policyholders first choice.

2. Pricewaterhouse Coopers Limited (PwC) made survey in China in the year 2012 and published report on Foreign Insurance Companies in China, www.pwcen.com This report focused on market issues foreign insurers in China, perspective of the market trend.

3. "Private Insurers Command Majority Share of Life Insurance Market" by Paramita Chatterjee in 2009. She plain said private insurers filmed $62 \%$ ontogeny measure in April-December 2008 against $45 \%$ in the same stop of net business. ICICI, HDFC, SBI and Bajaj Allianz are the predominant players of the living Contract sector. LIC a market trickster prerecorded a wane of $28 \%$ and experts said the Industry has witnessed a intelligent ontogenesis despite the fine financial conditions.

4. In 2003 "What's next in India's Insurance Market" by Kundu discussed the changes in various issues of Insurance Business after the accounting of new players. Despite of having huge universe, India still has a low protection perception. Today, fill are increasingly sensing 


\section{www.ijstrd.com}

not meet at products but at integrated business solutions that can offer a good returns along with complete protection. Technology will also play a crucial role in aiding plan and administrating of products as surface in efforts to build a good customer relationship.

\section{Objectives of the study}

1. To appraise the business performance of private sector in life insurance industries players in terms of total life insurance premium.

2. To evaluate the business performance of private life insurance players in terms of new business $-1^{\text {st }}$ year premium.

3. To appraise the performance of private sector in life insurance players in terms of new business - no of policies.

4. To examine the market share of private life insurance companies in India.

5. To compare the performance of life insurance industry and private life insurance companies.

\section{Period of the study}

The present study covers ten years from 2004-05 to 2014-15. This is the phase during which is around $27 \%$ of the Indian Insurance industry market assets captured by private shelter companies.

\section{Hypothesis}

Table 2: Total Life Insurance Premium Income (in crores)

\begin{tabular}{|c|c|c|c|c|}
\hline Financial Year & $\begin{array}{c}\text { Private } \\
\text { Insurance } \\
\text { Company }\end{array}$ & $\begin{array}{c}\text { Growth over } \\
\text { previous year } \\
\text { business (\%) }\end{array}$ & $\begin{array}{c}\text { Insurance } \\
\text { Industry }\end{array}$ & $\begin{array}{c}\text { Growth over } \\
\text { previous year } \\
\text { business (\%) }\end{array}$ \\
\hline $2004-05$ & 7727.51 & 147.65 & 82854.80 & 24.31 \\
\hline $2005-06$ & 15083.54 & 95.19 & 105875.76 & 27.78 \\
\hline $2006-07$ & 28242.48 & 87.24 & 156065.32 & 47.38 \\
\hline $2007-08$ & 51561.42 & 82.57 & 201351.41 & 29.01 \\
\hline $2008-09$ & 64497.43 & 25.09 & 221785.47 & 10.15 \\
\hline $2009-10$ & 79373.06 & 23.06 & 265450.37 & 19.69 \\
\hline $2010-11$ & 88165.24 & 11.08 & 291638.64 & 9.87 \\
\hline $2011-12$ & 84182.83 & $(4.52)$ & 287072.11 & $(1.57)$ \\
\hline $2012-13$ & 78398.91 & $(6.87)$ & 287202.49 & 0.05 \\
\hline $2013-14$ & 77340.90 & $(1.35)$ & 314283.20 & 9.43 \\
\hline $2014-15$ & 88433.49 & 14.32 & 328101.14 & 4.39 \\
\hline
\end{tabular}

Source: IRDA Annual Reports

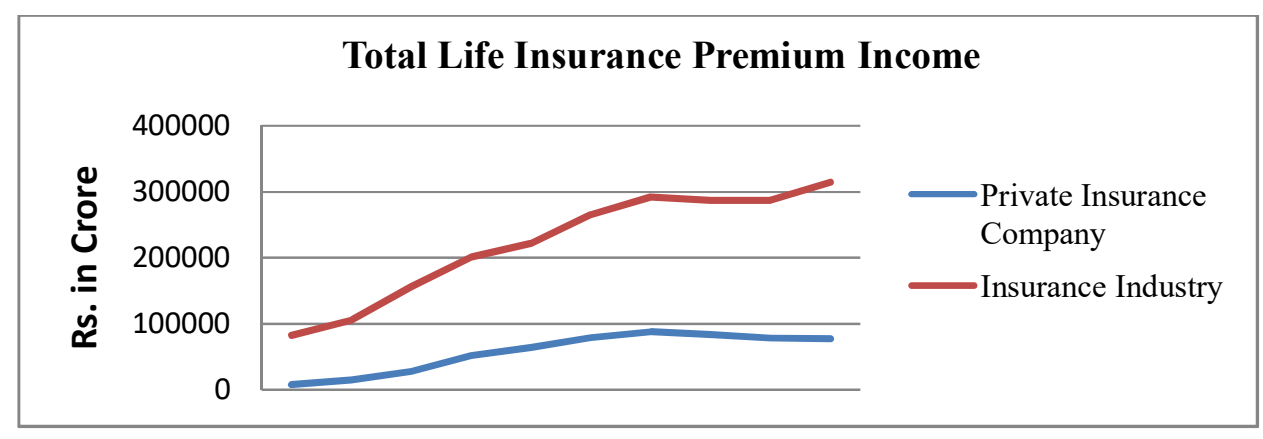

\section{B. New Business: First Year Premium (Including Single Premium)}

The measurable indicator of growing and performance of the shelter companies is -New Business in terms of First Year

\section{Null hypothesis}

There is no much difference in trends of development of private life shelter companies and life insurance industry of India.

\section{DATA COLLECTION AND ANALYSIS}

The learning is mainly based on inessential information which has been poised from the period reports of IRDA, IRDA journal and other literature available. A number of other online source which are related to insurance business such as bimaonline.com, irdaindia.com, licindia.com, etc have also been visited for the purpose to collect the information.

Table 1: Registered Insurers In India (As on $31^{\text {st }}$ March,2015)

\begin{tabular}{|c|c|c|c|}
\hline $\begin{array}{c}\text { Type of } \\
\text { Business }\end{array}$ & $\begin{array}{c}\text { Public } \\
\text { Sector }\end{array}$ & $\begin{array}{c}\text { Private } \\
\text { Sector }\end{array}$ & Total \\
\hline Life Insurance & 1 & 23 & 24 \\
Non-Life & 6 & 22 & 28 \\
Insurance & 1 & 0 & 1 \\
Reinsurance & & & \\
\hline Total & 8 & 45 & 53 \\
\hline
\end{tabular}

Source: IRDA Annual report -2014-15 P.No-8

\section{A. Total Life Insurance Income:}

Add premium income is one of the important and key indicators of the execution performance of the shelter business. 
Table 3: New Business - First Year Premium (in Crores)

\begin{tabular}{|c|c|c|c|c|}
\hline Financial Year & $\begin{array}{c}\text { Private Insurance } \\
\text { Company }\end{array}$ & $\begin{array}{c}\text { Growth over } \\
\text { previous year } \\
\text { business (\%) }\end{array}$ & $\begin{array}{c}\text { Insurance } \\
\text { Industry }\end{array}$ & $\begin{array}{c}\text { Growth over } \\
\text { previous year } \\
\text { business (\%) }\end{array}$ \\
\hline $2004-05$ & 5564.57 & 127.99 & 26217.64 & 32.49 \\
\hline $2005-06$ & 10269.67 & 84.55 & 38785.54 & 47.94 \\
\hline $2006-07$ & 19425.65 & 89.16 & 75649.21 & 95.04 \\
\hline $2007-08$ & 33715.95 & 73.56 & 93712.52 & 23.88 \\
\hline $2008-09$ & 34152.00 & 1.29 & 87331.08 & $(6.81)$ \\
\hline $2009-10$ & 38372.01 & 12.36 & 109893.91 & 25.84 \\
\hline $2010-11$ & 39385.84 & 2.64 & 126398.18 & 15.02 \\
\hline $2011-12$ & 32103.78 & $(18.49)$ & 113966.03 & $(9.84)$ \\
\hline $2012-13$ & 30749.58 & $(4.22)$ & 107361.08 & $(5.80)$ \\
\hline $2013-14$ & 29510.87 & $(4.03)$ & 120319.66 & 12.07 \\
\hline $2014-15$ & 34820.23 & 17.97 & 113327.94 & $(5.82)$ \\
\hline
\end{tabular}

Source: IRDA Annual Reports

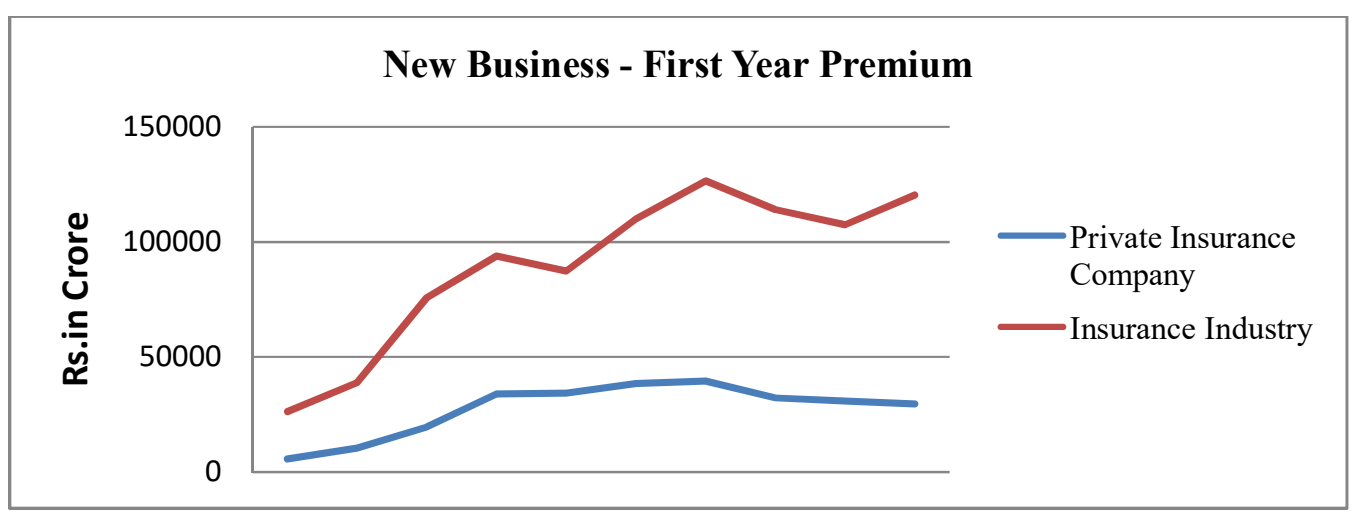

\section{New Business: no of Policies}

The fundamental indicator of development and performance of the insurance companies is -New Business in terms of no of
Policies. Table - 4 shows the New Business: no of Policies sold by Private insurance companies and Insurance industry. It also presents the growth rate of New Business: no of Policies.

Table - 4: New Business - no of Policies (In Lacs)

\begin{tabular}{|c|c|c|c|c|}
\hline Financial Year & $\begin{array}{c}\text { Private Insurance } \\
\text { Company }\end{array}$ & $\begin{array}{c}\text { Growth over } \\
\text { previous year } \\
\text { business (\%) }\end{array}$ & $\begin{array}{c}\text { Insurance } \\
\text { Industry }\end{array}$ & $\begin{array}{c}\text { Growth over } \\
\text { previous year } \\
\text { business (\%) }\end{array}$ \\
\hline $2004-05$ & 22.33 & 34.62 & 262.11 & $(8.4)$ \\
\hline $2005-06$ & 38.71 & 73.37 & 354.62 & 35.30 \\
\hline $2006-07$ & 79.22 & 104.64 & 461.52 & 30.10 \\
\hline $2007-08$ & 132.62 & 67.40 & 508.74 & 10.20 \\
\hline $2008-09$ & 150.11 & 13.19 & 509.23 & 0.10 \\
\hline $2009-10$ & 143.62 & $(4.32)$ & 532.25 & 4.52 \\
\hline $2010-11$ & 111.14 & $(22.61)$ & 481.52 & $(9.53)$ \\
\hline $2011-12$ & 84.42 & $(24.04)$ & 441.93 & $(8.22)$ \\
\hline $2012-13$ & 74.05 & $(12.28)$ & 441.87 & $(0.01)$ \\
\hline $2013-14$ & 63.60 & $(14.11)$ & 408.72 & $(7.50)$ \\
\hline $2014-15$ & 57.37 & $(9.79)$ & 259.08 & $(36.61)$ \\
\hline
\end{tabular}

Source: IRDA Annual Reports 


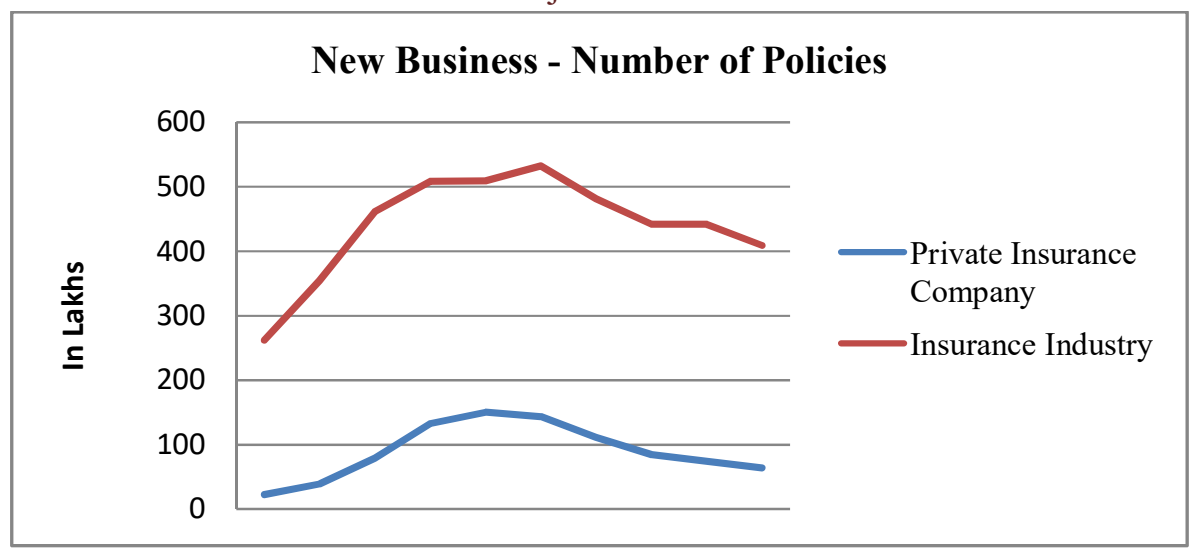

\section{Market Share}

Market acquire is also an key indicator of development and execution of the any insurance companies. Activity percentage is the percentage of assets captured by any insurance organization. A company with high market share reflects strong market value and position. Table -4 shows the Market Share (In terms of Total Premium \& Renewal Premium) recorded by Private insurance companies in Indian insurance market.

Table 4: Market Share of Private Insurance Companies (In Percentage)

\begin{tabular}{|c|c|c|c|}
\hline Financial Year & $\begin{array}{c}\text { In terms of Total } \\
\text { Premium }\end{array}$ & $\begin{array}{c}\text { In terms of Renewal } \\
\text { Premium }\end{array}$ & $\begin{array}{c}\text { In terms of First Year } \\
\text { Premium }\end{array}$ \\
\hline $2004-05$ & 9.33 & 3.82 & 26.59 \\
\hline $2005-06$ & 14.24 & 7.18 & 26.48 \\
\hline $2006-07$ & 18.10 & 10.98 & 25.65 \\
\hline $2007-08$ & 25.60 & 16.58 & 35.98 \\
\hline $2008-09$ & 29.08 & 22.57 & 38.88 \\
\hline $2009-10$ & 29.90 & 26.36 & 34.92 \\
\hline $2010-11$ & 30.23 & 29.52 & 31.15 \\
\hline $2011-12$ & 29.32 & 30.09 & 28.15 \\
\hline $2012-13$ & 27.30 & 26.50 & 28.64 \\
\hline $2013-14$ & 24.61 & 24.66 & 24.53 \\
\hline $2014-15$ & 26.95 & 24.96 & 30.73 \\
\hline
\end{tabular}

Source: IRDA Annual Reports

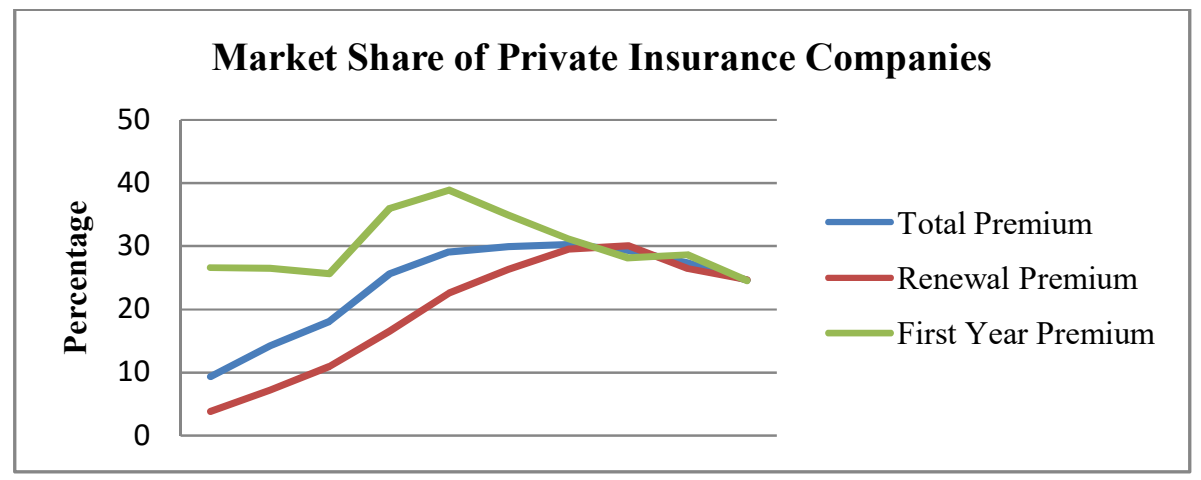

\section{Findings}

1. From 2010-11 to 2014-15, total life insurance premium income having very low increase of private insurance companies as compared to positive growth of insurance industry.

2. From 2010-11 to 2014-15, first year premium (Including Single Premium) income is higher increase of private insurance companies as compared to insurance industry.

3. There is a sharp decline in New Business: Number of Policies selling of insurance industry as compared to private insurance companies.

4. The market share of private insurance companies reached to $30.23 \%, 30.09 \%$ and $34.92 \%$ in terms of total premium, renewal premium and first year premium respectively but then it declines to almost $25 \%$ in all three sectors.

\section{CONCLUSION}

1. Number of private insurance companies reached to 23 in one decade.

2. Business in all sectors rapidly increased up to 201011 then down trend started which shows that Indian insurance customer's have bad experience with private companies and now they are less interested towards the private insurance companies.

3. Losing of market share concludes that there are some problems with private insurance companies related with insurance product, premium amount, and service quality or other. 


\section{Suggestion}

1. Private insurance companies have to seriously think about continues down fall.

2. Try to find out the causes of losing confidence of Indian insurance customer's.

3. Introduce Indian market friendly insurance products, low premium \& high risk cover products, improve service quality, target rural market etc.

\section{References}

[1] Swiss Re, Sigma, Various Issues, Source: IRDA Annual report -2013-14, P.-8
[2] Dr.Anshuja Tiwari \& Babita Tiwari, 2012, Analytical study on Indian Life Insurance Industry in Post Liberalisation

[3] Ravichandran K., 2007,Recent Trends in Insurance Sector in India, Abijeet Publications, Delhi

[4] Summinder Kaur Bawa, 2007, Life Insurance Corporation of India - Impact of Privatization and Performance, Regal Publications, New Delhi

[5] Chairman's Statement, IRDA Annual Report 200001, P-1.

[6] IRDA Annual Report 2000-01, P-10.

[7] C.R. Kothari, 1996, Research Methodology - Methods \& Techniques, Wishwa Prakashan, New Delhi

[8] www.irda.org 